Portland State University

PDXScholar

$5-22-2020$

\title{
The Role of Redox Chemistry of Disulfide Bonds in Cysteine Residues of Membrane Proteins by Cuprous and Cupric lons in Cell Death of E. coli
}

Morgan R. Stewart

Portland State University

Follow this and additional works at: https://pdxscholar.library.pdx.edu/honorstheses

Part of the Biochemistry Commons

Let us know how access to this document benefits you.

Recommended Citation

Stewart, Morgan R., "The Role of Redox Chemistry of Disulfide Bonds in Cysteine Residues of Membrane Proteins by Cuprous and Cupric Ions in Cell Death of E. coli" (2020). University Honors Theses. Paper 841. https://doi.org/10.15760/honors.860

This Thesis is brought to you for free and open access. It has been accepted for inclusion in University Honors Theses by an authorized administrator of PDXScholar. Please contact us if we can make this document more accessible: pdxscholar@pdx.edu. 
The role of redox chemistry of disulfide bonds in cysteine residues of membrane proteins by cuprous and cupric ions in cell death of $E$. coli

\author{
by \\ Morgan Stewart \\ An undergraduate honors thesis submitted in partial fulfillment of the

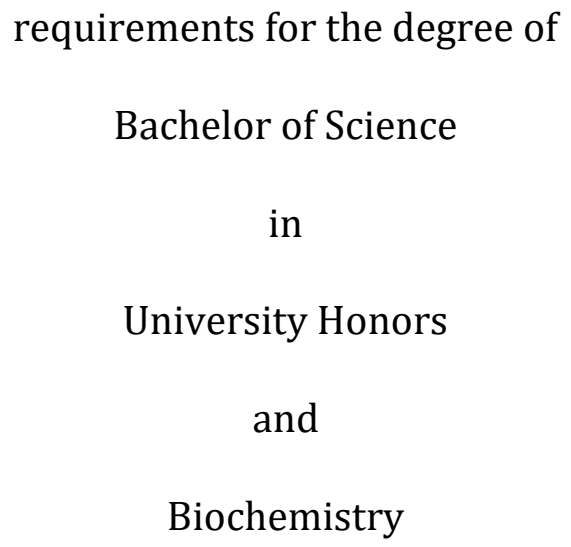




\begin{abstract}
The antimicrobial properties of copper have been thoroughly researched, but is still unclear what the actual mechanism of cell death is. This study explores the theory that copper ions and other copper sources act as an antibiotic for $E$. coli by cleaving the disulfide bonds of membrane proteins through redox chemistry, disrupting the cell membrane and causing cell death. The focus of this study is $\mathrm{Cu}(\mathrm{I})$ and $\mathrm{Cu}(\mathrm{II})$ interactions with the thiol containing amino acid, cysteine, and how these interactions may be responsible for copper's toxicity. Cuprous ions have been found to be more toxic to E.coli than cupric ions. The difference between cysteine's reactions with $\mathrm{Cu}(\mathrm{I})$ and $\mathrm{Cu}(\mathrm{II})$ are explored.
\end{abstract}

\section{INTRODUCTION}

Copper is a well known antimicrobial agent for a variety of organisms, including the bacteria Eschericia coli. It's toxicity has been shown in different forms of the metal, such as dry metallic surfaces ${ }^{1}$, nanostructures ${ }^{2,3}$, and ions ${ }^{4,5}$. Copper can be highly reactive in its ionic forms due to its ability to perform redox reactions. Because of this reactivity, there are many possible explanations for its toxicity. Previous theories suggest that an excess of reactive copper ions in the cell would create reactive oxidative species (ROS). ROS could cause damage to lipids in the cell membrane or damage genetic material, DNA and lead to mutations, which would lead to cell death. These proposals, however, have either been shown to be less likely or have less evidence to suggest they are the main cause of cell death $^{6}$. Another theory, which involves the destruction of proteins, either membrane or intracellular, has received more attention in recent years, and is the one that will be explored in this study.

Humans rely on many microorganisms to fulfill a range of functions that we do not have the means to perform ourselves ${ }^{7}$. This relationship we have with such organisms depends on balance and control ${ }^{7}$. Among the bacteria humans host is $E$. coli ${ }^{7}$, however, in the wrong system, or the wrong amount, or even the wrong type, E. coli can be dangerous ${ }^{7,8,9}$. Antibiotic agents have been studied for a long time due to their importance in returning control when the bacteria present become dangerous. As antibiotics were introduced to strains of bacteria, individual organisms which were genetically resistant to a particular kind of antibiotic would live on and reproduce, rendering the antibiotic ineffective, as the new strain of bacteria was now resistant to it $^{10}$.

E. coli is a gram-negative bacteria ${ }^{11}$, meaning the cellular envelope of the bacteria is composed of an asymmetrical outer membrane layer in addition to the peptidoglycan inner membrane layer ${ }^{12}$. This asymmetry of the outer membrane is caused by the inclusion of both glycerophospholipids (a lipid containing a glycerol-3-phosphate backbone and positions 1 and 2 esterified with fatty acyl chains), and lipopolysaccharides (a glycolipid composed of lipid A, core oligosaccharide, and O-antigen domains) ${ }^{12}$. The purpose of the outer membrane composition's asymmetry is to act as protection for the organism. The outer membrane allows for restriction of both large polar molecules, which would normally be restricted by a phospholipid bilayer, and lipophilic molecules ${ }^{12}$. The organization of the cellular envelope of gram-negative bacteria allows it to be highly 
selective about what can enter the cell, making the organism largely reliant on membrane proteins to bring nutrients and waste into and out of the cell respectively.

The proposed mechanism of denaturation of membrane proteins in $E$. coli involves the redox chemistry of the thiol groups of cysteine groups. Rigo et al. reports complexes formed cysteine and $\mathrm{Cu}(\mathrm{II})$, and the UV-Visible absorption spectrum associated with such complexes ${ }^{13}$. Often these complexes are utilized by the cell for catalytic function, or to bind copper for transport throughout the cell ${ }^{14}$. Cysteine residues are also known to be found in membrane proteins such as transport proteins ${ }^{15}$. Proposed here is the theory that these complexes are formed, not with catalytic cysteine residues, but with structural ones, specifically in membrane proteins.

Previous experiments conducted in Dr. Shankar Rananavare's lab at Portland State University found that in a comparison between copper nanowires, nanoparticles, and both the cupric and cuprous ionic forms, that $\mathrm{Cu}(\mathrm{I})$ had the highest antimicrobial effect when exposed to E. coli (Appendix A). Similar results are reported by Park et al, finding that $\mathrm{Cu}(\mathrm{I})$ has a higher antimicrobial effect on $E$. coli than $\mathrm{Cu}(\mathrm{II})^{16}$. The purpose of this study is to explain the discrepancy between the different forms of copper and their toxicity levels, and explore the mechanism by which copper achieves cell death in E. coli.

Antimicrobial properties of copper lead to the question: how does copper cause cell death? The mechanism of copper induced cell death remains unclear. Many theories have been proposed to explain this phenomenon, including damage to DNA, proteins, or lipids or some combination thereof. Some studies have observed the rupturing of the cellular envelope with exposure to copper, while other studies have explained how copper disrupts protein structure and catalytic ability. This study aims to gain insight into one mechanism, which has shown a lot of promise as the leading cause. Specifically, we will examine why the mechanism proposed, disruption of membrane proteins through oxidation or reduction of disulfide bonds of cysteine residues, is more likely than others.

Additionally, this study will examine the differences between $\mathrm{Cu}(\mathrm{I})$ and $\mathrm{Cu}(\mathrm{II})$ interactions with cysteine and attempt to explain why one would be more effective than the other.

\section{LITERATURE REVIEW}

The effects of exposing $E$. coli to copper in various forms such as dry metallic surfaces, nanostructures, and ionic solutions, has been studied previously in literature. The results of such experiments will be reviewed and discussed here. As previously stated, one proposed theory, the damage of DNA, has been ruled out, in favor of the theory of protein damage. A discussion of why this is will be included. Because the mechanism theorized in this study as the cause of cell death suggests the oxidation of the disulfide bonds of thiol groups of membrane proteins, both the role of cysteine residues in proteins known in $E$. coli will also be discussed. In addition, previous studies which focus on the effect of copper on disulfide bonds will be reviewed and discussed. Lastly, previous studies of copper ion interactions with cysteine have been conducted with cupric ions, this study aims to gain insight into how $\mathrm{Cu}$ (I) ions would behave in place of $\mathrm{Cu}$ (II) ions in the same mechanisms, and why a difference was observed in the two in preliminary experiments. 


\section{Copper's Antibacterial Effects}

There have been many studies on the effectiveness of different forms of copper (dry metallic surfaces, nanomaterials, and ions) as an antibacterial agent, which have all reported similar findings, that copper's ability to kill bacteria is rapid, and effective $^{1,2,4,14,17,18,19,20,21}$. Dry metallic copper has been used by humans for the purpose of sterilization from as early as $2000 \mathrm{BC}^{22}$. More recently, copper is a popular choice for biomedical applications due to copper alloy surfaces' ability to kill up to $99 \%$ of bacteria within two hours ${ }^{22}$. Some antimicrobial agents cause the organism affected to become "non-viable", meaning they are not destroyed, but only unable to reproduce. Copper has the ability to completely inactivate bacteria ${ }^{22}$. Because of this, copper has been registered by the Environmental Protection Agency (EPA) as one of the only antimicrobial solid surfaces that can do $\mathrm{so}^{22}$. Additionally, it has been reported that copper has the fastest inactivation rate for human coronavirus, with the longest reported lifetime for the virus on copper surfaces being 4 hours $^{23}$.

The search for more efficient antibacterial technology is being pushed forward as many strains of organisms become resistant to previously used antibiotics. The success of copper surfaces' ability to act as an antimicrobial agent has led to the development and use of copper nanostructures for the same purpose, with hopes of increasing surface area, and increasing effectiveness. Nanostructures are a classification of materials in the nanoscale, including nanoparticles, nanowires, and many more ${ }^{24}$. Recent studies of copper oxide nanomaterials' toxicity to bacteria have shown that against Staphylococcus epidermidis, $\mathrm{CuO}$ nanoparticles above 100 $\mu \mathrm{g} / \mathrm{mL}$ render the bacteria inviable ${ }^{2}$.
Another recent study, which included the effects of copper nanoparticles on both gram-negative and gram-positive bacteria found that presence of copper nanowires greatly reduced growth of both types of organisms ${ }^{21}$.

Santo et al. hypothesized that the effects of copper on E. coli exposed to dry metallic surfaces are due to the ionization of surface copper molecules into either $\mathrm{Cu}(\mathrm{I})$ or $\mathrm{Cu}(\mathrm{II})$ ionic states and their effect on the bacteria $^{1}$. Due to its high enthalpy of hydration, copper ions are highly unstable in an aqueous environment ${ }^{19}$, and, in the presence of oxygen, these ions can produce highly reactive oxidative species (ROS) ${ }^{13}$. These ROS can be damaging to DNA, which is the proposed mechanism for cell death through effects to DNA ${ }^{13}$. Copper's two most common ionic forms, $\mathrm{Cu}(\mathrm{I})$ and $\mathrm{Cu}(\mathrm{II})$, both have positive reduction potentials which makes them oxidizing agents. Previous studies on the effects of copper ions on $E$. coli have shown that exposure to copper acetate or copper nitrate destroys the cell wall and inactivates the cell in an hour or less ${ }^{4,19}$ just as seen in experiments with dry metallic surfaces.

\section{Membrane vs. DNA Damage}

Because copper can be highly reactive when in its ionic forms, there are many possibilities for the reason to its toxicity. Previously, one theory suggests that an excess of reactive copper ions in the cell would cause DNA mutations causing cell death. However, recent research has shown that this is not the case, and in fact, increase in copper ions in the cell affects copper permeability through the cell membrane wall ${ }^{6}$. When there is an excess of copper ions in the cell, the ComR gene, which is responsible for production of membrane protein ComC, is signaled to stop 
production, thus reducing copper ion intake $^{6}$, which would prevent interactions between copper and DNA. In addition to this, cells exposed to copper nanoparticles have been found to have cavities in their cell walls $^{3}$, supporting the theory that copper is affecting the membrane. Additionally, in studies which observed $E$. coli when exposed to copper ions, damage to the cell membrane occurred rapidly ${ }^{18}$.

\section{Cysteine's Role in Membrane Proteins}

Cysteine can serve many roles in a protein, depending on where it is located in the sequence, and where the protein is placed. Because of its polar nature and easily oxidized thiol group, cysteine can either coordinate metals, serve as a structural element, or participate in regulation of protein function ${ }^{13,25}$. There are two types of cysteine bonds in proteins ${ }^{26}$. Proteins with structural disulfide cysteine bonds are hardly found in cytoplasmic proteins ${ }^{26}$. If cell death is mainly caused by disruption of the membrane, and the denaturation of membrane proteins is the source of this disruption, it stands to reason that looking at how copper interacts with cysteine is a good place to start in an explanation of copper's role in cell death.

\section{Copper's Effect on Proteins and Cysteine}

While copper can be toxic to many organisms, not just bacteria ${ }^{17,19}$, it is essential in certain levels for some biological functions ${ }^{13,15}$. Copper is often used as a cofactor in certain proteins, and is utilized for its ability to perform redox chemistry ${ }^{15}$. Because it is needed in the cell, $E$. coli has established pathways for dealing with it in the cell at biological concentrations $^{27}$. It is proposed that at high concentrations, when the cell cannot handle the amount of copper it is exposed to, that toxicity occurs.

There are several proposed theories which attempt to explain what exactly copper does to proteins to cause damage. One such theory suggests that copper ions oxidize active sites on catalytic reducing groups, such as cysteine residues, thus rendering them inactive $\mathrm{e}^{2,28}$. Another focuses on the structural role of disulfide bonds in protein folding, and how the breaking of such integral structural components could cause cell death by "membrane fouling" $29,30 . \mathrm{Cu}$ toxicity via damage to proteins may also be due to displacement of essential metals ${ }^{30}$. In much of the literature, these processes are dependent on the complexing or oxidation reactions of copper and cysteine $\mathrm{e}^{13,21,28,30,31,32,33}$.

\section{Cupric vs. Cuprous Ions.}

The standard reduction potentials of $\mathrm{Cu}(\mathrm{I})$ and $\mathrm{Cu}(\mathrm{II})$ are 0.518 and 0.161 , making $\mathrm{Cu}(\mathrm{I})$ a stronger oxidizing agent than $\mathrm{Cu}(\mathrm{II})^{34}$. Park et al. supports the finding that $\mathrm{Cu}(\mathrm{I})$ has a higher toxicity to $E$. coli than $\mathrm{Cu}$ (II), and proposes that the mode of inactivation of the cell is not due to reactive oxidative species formed by copper ions, but by the copper ions themselves ${ }^{16}$.

\section{METHODS}

\section{Absorption of copper-cysteine complexes}

Absorption spectra of cysteine's complexes with both $\mathrm{Cu}(\mathrm{I})$ and $\mathrm{Cu}(\mathrm{II})$ ions were collected through UV-Visible spectrophotometer. All trials were done in anaerobic conditions using nitrogen gas. Cuprous and cupric chloride salts were used as the source of copper ions. Due to cuprous 
chloride's low solubility in water, a phosphate buffer of $\mathrm{pH}$ 6.1-6.4 was used as the mixing solution. The phosphate buffer consisted of $0.0607 \mathrm{M} \mathrm{NaH}_{2} \mathrm{PO}_{4}$ and 0.0136 $\mathrm{M} \mathrm{Na}_{2} \mathrm{HPO}_{4}$. The concentration of cysteine across all trials was maintained at $1.3 \mathrm{mM}$. Concentrations of copper ions were analyzed at 0.63 and $0.33 \mathrm{mM}$. The coppercysteine solutions were prepared by first adding the cysteine aliquot to the buffer, bubbling $\mathrm{N}_{2}$ gas through the solution, then adding the copper ion aliquot (to make either 0.63 or $0.33 \mathrm{mM}$ ), and bubbling with $\mathrm{N}_{2}$ once more before spectrum was collected. Absorption spectra were collected using an Agilent 8453 UV-Visible Spectrophotometer.

\section{Absorption of cysteine at varying concentrations}

In preliminary tests, a discrepancy between the absorption peak of cysteine was observed at different concentrations. This prompted a test of an analysis of concentration of uncomplexed cysteine at varying concentrations, in order to identify concentrations of uncomplexed cysteine in further trials. This analysis involved comparing cysteine's absorbance peak over a concentration range of $10-100 \mathrm{mM}$ in both deionized water and in the phosphate buffer used in the UV-Visible spectra of coppercysteine complexes.

\section{Preparation of $\mathrm{CuNO}_{3}$}

Copper nitrate was prepared by combining solid copper chloride with aqueous silver nitrate through the reaction

$$
\mathrm{CuCl}+\mathrm{AgNO}_{3} \rightarrow \mathrm{CuNO}_{3}+\mathrm{AgCl}
$$

The silver nitrate was filtered out and the copper nitrate was diluted to $0.63 \mathrm{mM}$ and mixed with $1.13 \mathrm{mM}$ cysteine in phosphate buffer.

\section{RESULTS AND DISCUSSION}

The first comparison of $\mathrm{Cu}$ (I) and $\mathrm{Cu}$ (II) interactions with cysteine, used cuprous and cupric chloride. Their spectra show a strong peak at around $200 \mathrm{~nm}$ (Figure 1). Pecci et al. reports the absorbance spectrum of $\mathrm{Cu}(\mathrm{II})$-cysteine complexes to have a peak at $260 \mathrm{~nm}$ and a shoulder at $300 \mathrm{~nm}^{33}$. These two characteristics are present in t Figure 1 for the solution prepared to be a $\mathrm{Cu}(\mathrm{I})$ cysteine complex. This indicates that in the sampling process, some of the $\mathrm{Cu}((\mathrm{I})$ was oxidized to $\mathrm{Cu}(\mathrm{II})$. These findings suggested a different method of preparation of $\mathrm{Cu}(\mathrm{I})$ ions was needed. Additionally, neither of these peaks are present in the solution prepared to be a $\mathrm{Cu}$ (II)-cysteine complex. The cause of this is unknown.

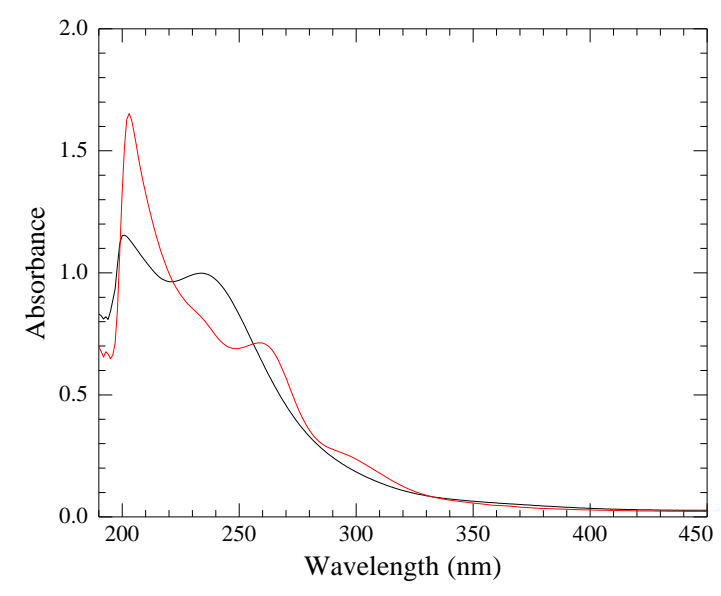

Figure 1: UV-Visible absorbance of $1.13 \mathrm{mM}$ cysteine with $0.63 \mathrm{mM} \mathrm{CuCl}$ (red), and $0.63 \mathrm{CuCl}_{2}$ (black) in deoxygenated phosphate buffer.

Observed in the $\mathrm{Cu}(\mathrm{II})$-cysteine complex in addition to the peak at 200, is a peak over the range $230-250 \mathrm{~nm}$. A possible explanation for this peak is cysteine which did not bind into a complex with copper. Figure 2 shows the absorbance peak of cysteine falls between 235 and 245 , depending on the concentration. Figure 2 also shows the effects of the phosphate 
buffer on cysteine's UV-Visible spectrum. When compared to a cysteine dilution done in deionized water, several unidentified peaks are observed. This led to the conclusion that a different buffer be used when observing cysteine-containing samples. It is unclear what causes cysteine to have a shift in absorbance as the concentration increases. An analysis of the relationship between the major peak wavelength and the concentration of cysteine yields a linear trendline in both the phosphate buffer and water (Figure 3).
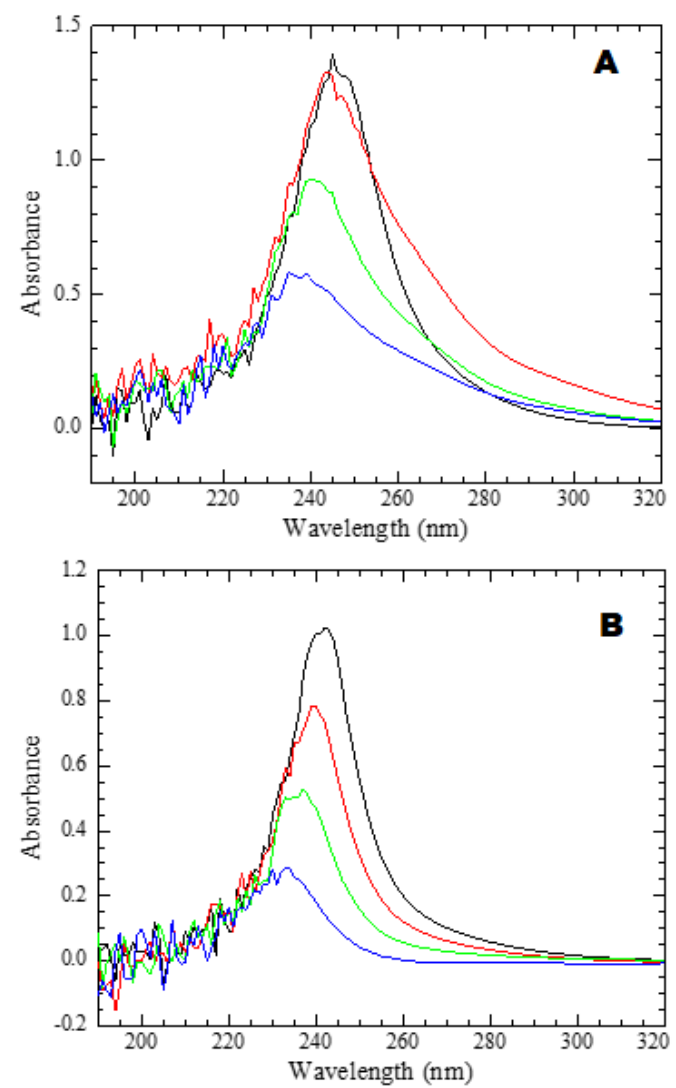

Figure 2: UV-Visible absorption spectra of cysteine dilutions in phosphate buffer (A) and deionized $\mathrm{H}_{2} \mathrm{O}$ (B). Black: $100 \mathrm{mM}$, Red: $50 \mathrm{mM}$, Green: $25 \mathrm{mM}$, Blue: $10 \mathrm{mM}$.

The slope of the curve for cysteine in the phosphate buffer is $10 \pm 2$, and the $y$ intercept is $225 \pm 3$. The slope for cysteine in water is $9 \pm 0.6$ and the $y$-intercept is $224.1 \pm 0.9$. There is not significant difference between these results, which indicates that a change in peak wavelength is not caused by matrix effects in the buffer, but is instead a property of cysteine itself.
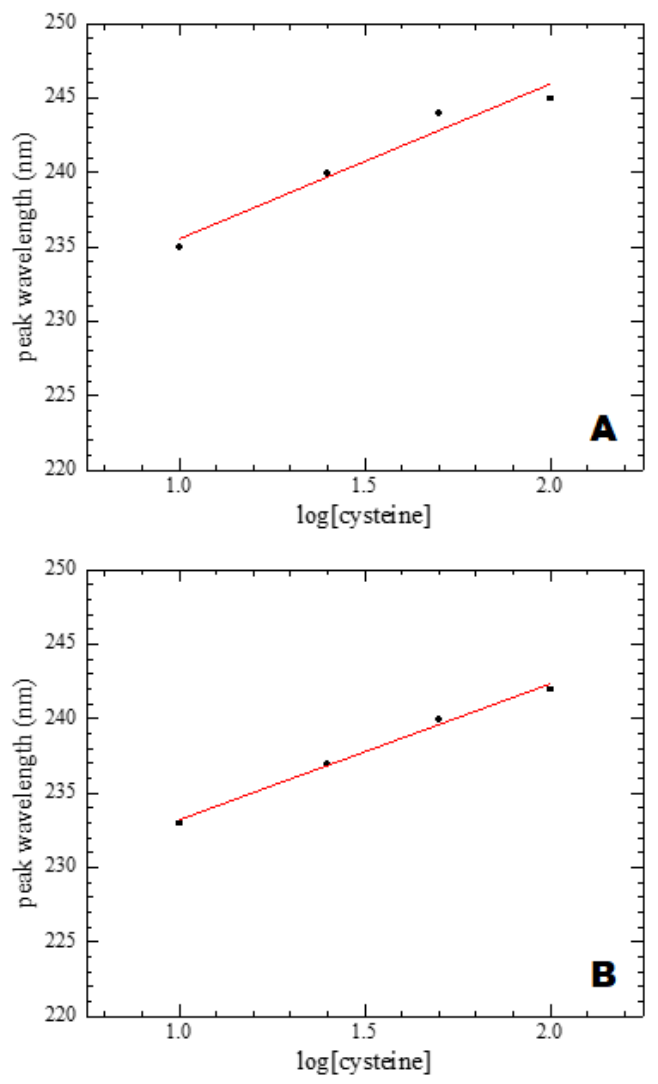

Figure 3: Plot of logarithm of concentration of cysteine $(\mathrm{mM})$ versus absorption peak wavelength $(\mathrm{nm})$ in $\mathrm{pH} 6.2$ phosphate buffer (A) and in deionized water (B).

In addition to the $\mathrm{Cu}(\mathrm{II})$-cysteine peaks observed in the red curve of Figure 1, there is also a shoulder present around $230 \mathrm{~nm}$ and a soft peak around $260 \mathrm{~nm}$. The UVVisible spectrum of cystine, the dimer form of cysteine, has been reported to have such characteristics $^{35}$. The redox potential of the coupling of two cystine molecules into one cystine is $-0.22 \mathrm{~V}^{36}$. Taking into consideration the reduction potentials of both $\mathrm{Cu}(\mathrm{I})$ and $\mathrm{Cu}(\mathrm{II})$, the formation of cystine is possible, and is the most likely cause of the peaks observed in the red curve of Figure 1. 
The unclear results shown in Figure 1 were theorized to be due to the low solubility of $\mathrm{CuCl}$. It is possible that the absorbance spectra appearing closer to the expected spectra of a $\mathrm{Cu}$ (II) complex with cysteine was observed because $\mathrm{Cu}(\mathrm{I})$ was being oxidized to $\mathrm{Cu}(\mathrm{II})$, which would allow it to enter solution, and complex with cysteine. A new source of $\mathrm{Cu}(\mathrm{I})$ ions, $\mathrm{CuNO}_{3}$ was chosen for a second test for complexed formed between cysteine and $\mathrm{Cu}(\mathrm{I})$. The result of $\mathrm{CuNO}_{3}$ with cysteine is shown in Figure 4. This spectrum shows a rough peak around $245 \mathrm{~nm}$. Because cysteine has been shown to have an absorbance peak at 245 at the concentration used in this trial, and no other clear peaks are seen, it can concluded that copper nitrate did not interact with cysteine. During the filtration process, the copper nitrate solution was exposed to air, which may have caused it to become oxidized, however, the characteristic peak and shoulder associated with a $\mathrm{Cu}$ (II)cysteine complex was not observed.

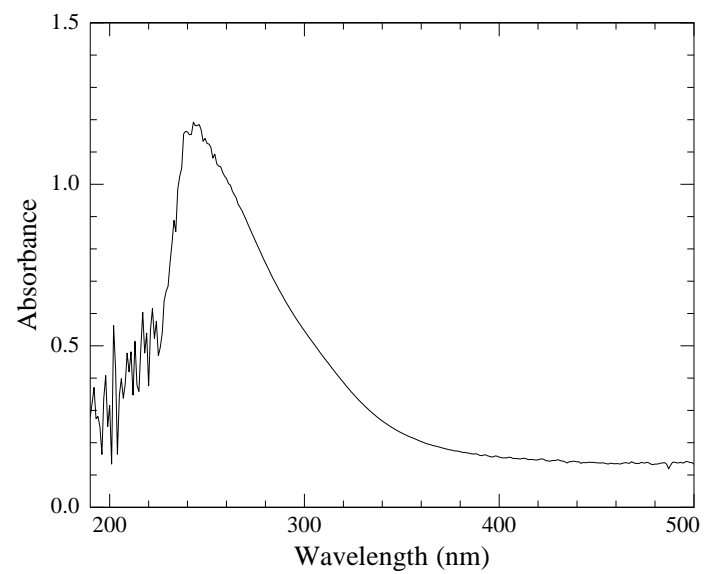

Figure 4: UV-Visible spectrum of $0.63 \mathrm{mM} \mathrm{CuNO}_{3}$ with $1.13 \mathrm{mM}$ cysteine in phosphate buffer .

In conclusion, results from previous studies which indicate a characteristic absorption peak for $\mathrm{Cu}$ (II)-cysteine complexes was confirmed in this study. Additionally, the literature review provides evidence for theory that copper acts as an antibacterial agent in E. coli due to damage caused to membrane proteins through redox chemistry with thiol groups. In order to further explore this hypothesis, the following procedures are proposed: a more thorough analysis of the interactions between $\mathrm{Cu}(\mathrm{I})$ and cysteine, and, using results obtained from such analysis, an investigation into the presence of such copper-cysteine complexes in E. coli exposed to copper ions. This may be implemented using methods such as the detection of cleaved disulfide bonds using Ellman's reagent.

\section{REFERENCES}

1: Santo Christophe Espírito; Taudte, N.; Nies, D. H.; Grass, G. Contribution of Copper Ion Resistance to Survival of Escherichia Coli on Metallic Copper Surfaces. Applied and Environmental Microbiology 2007, 74 (4), 977-986.

2: Badetti, E.; Calgaro, L.; Falchi, L.; Bonetto, A.; Bettiol, C.; Leonetti, B.; Ambrosi, E.; Zendri, E.; Marcomini, A. Interaction between Copper Oxide Nanoparticles and Amino Acids: Influence on the Antibacterial Activity. Nanomaterials 2019, 9 (5), 792.

3: Raffi, M.; Mehrwan, S.; Bhatti, T. M.; Akhter, J. I.; Hameed, A.; Yawar, W.; Hasan, M. M. U. Investigations into the Antibacterial Behavior of Copper Nanoparticles against Escherichia Coli. Annals of Microbiology 2010, 60 (1), 75-80.

4: Luo, J.; Hein, C.; Pierson, J.-F.; Mücklich, F. Early-Stage Corrosion, Ion Release, and the Antibacterial Effect of Copper and Cuprous Oxide in Physiological Buffers: Phosphate-Buffered Saline vs Na-4-(2-Hydroxyethyl)-1-Piperazineethanesulfonic Acid. Biointerphases 2019, 14 (6), 061004.

5: Nan, L.; Liu, Y.; Lü, M.; Yang, K. Study on Antibacterial Mechanism of Copper-Bearing Austenitic Antibacterial Stainless Steel by Atomic Force Microscopy. Journal of Materials Science: Materials in Medicine 2008, 19 (9), 3057-3062.

6: Mermod, M.; Magnani, D.; Solioz, M.; Stoyanov, J. V. The Copper-Inducible ComR (YcfQ) Repressor Regulates Expression of ComC (YcfR), Which 
Affects Copper Permeability of the Outer Membrane of Escherichia Coli. BioMetals 2011, 25 (1), 33-43. 7: Fijan, S. Microorganisms with Claimed Probiotic Properties: An Overview of Recent Literature. International Journal of Environmental Research and Public Health 2014, 11 (5), 47454767.

8: Hammerum, A. M.; Heuer, O. E. Human Health Hazards from Antimicrobial-ResistantEscherichia Coliof Animal Origin. Clinical Infectious Diseases 2009, 48 (7), 916-921.

9: Fioramonti, J.; Theodorou, V.; Bueno, L. Probiotics: What Are They? What Are Their Effects on Gut Physiology? Best Practice \& Research Clinical Gastroenterology 2003, 17 (5), 711-724.

10: Demerec, M. Origin of Bacterial Resistance to Antibiotics 1. Journal of Bacteriology 1948, 56 (1), 63-74.

11: Sondi, I.; Salopek-Sondi, B. Silver Nanoparticles as Antimicrobial Agent: a Case Study on E. Coli as a Model for Gram-Negative Bacteria. Journal of Colloid and Interface Science 2004, 275 (1), 177182.

12: Henderson, J. C.; Zimmerman, S. M.; Crofts, A. A.; Boll, J. M.; Kuhns, L. G.; Herrera, C. M.; Trent, M. S. The Power of Asymmetry: Architecture and Assembly of the Gram-Negative Outer Membrane Lipid Bilayer. Annual Review of

Microbiology 2016, 70 (1), 255-278.

13: Rigo, A.; Corazza, A.; Paolo, M. L. D.; Rossetto, M.; Ugolini, R.; Scarpa, M. Interaction of Copper with Cysteine: Stability of Cuprous Complexes and Catalytic Role of Cupric Ions in Anaerobic Thiol Oxidation. Journal of Inorganic Biochemistry 2004, 98 (9), 1495-1501.

14: Grass, G.; Rensing, C.; Solioz, M. Metallic Copper as an Antimicrobial Surface. Applied and Environmental Microbiology 2010, 77 (5), 15411547.

15: Tusnády, G. E.; Simon, I. Principles Governing Amino Acid Composition of Integral Membrane Proteins: Application to Topology Prediction 1 1Edited by J. Thornton. Journal of Molecular Biology 1998, 283 (2), 489-506.

16: Park, H.-J.; Nguyen, T. T. M.; Yoon, J.; Lee, C. Role of Reactive Oxygen Species InEscherichia ColiInactivation by Cupric Ion. Environmental Science \& Technology 2012, 46 (20), 11299-11304.
17: Wilks, S. A.; Michels, H. T.; Keevil, C. W. Survival of Listeria Monocytogenes Scott A on Metal Surfaces: Implications for Cross-

Contamination. International Journal of Food Microbiology 2006, 111 (2), 93-98.

18: Santo, C. E.; Lam, E. W.; Elowsky, C. G.; Quaranta, D.; Domaille, D. W.; Chang, C. J.; Grass, G. Bacterial Killing by Dry Metallic Copper Surfaces. Applied and Environmental Microbiology 2010, 77 (3), 794-802.

19: Zanzen, U.; Bovenkamp-Langlois, L.; Homes, J.; Prange, A. The Interaction of Copper Ions with Staphylococcus Aureus, Pseudomonas Aeruginosa, and Escherichia Coli: and X-Ray Absorbtion nearEdge Structure (XANES) Spectroscopy Study. Archive of Microbiology 2019, 200 (3), 401412.

20: Borkow, G.; Gabbay, J. Copper as a Biocidal Tool. Current Medicinal Chemistry 2005, 12 (18), 2163-2175.

21: Lv, P.; Zhu, L.; Yu, Y.; Wang, W.; Liu, G.; Lu, $\mathrm{H}$. Effect of $\mathrm{NaOH}$ Concentration on Antibacterial Activities of $\mathrm{Cu}$ Nanoparticles and the Antibacterial Mechanism. Materials Science and Engineering: C 2020, 110, 110669.

22: Borkow, G.; Gabbay, J. Copper, An Ancient Remedy Returning to Fight Microbial, Fungal and Viral Infections. Current Chemical Biology 2009, 3 (3), 272-278.

23: Warnes, S. L.; Little, Z. R.; Keevil, C. W. Human Coronavirus 229E Remains Infectious on Common Touch Surface Materials. mBio 2015, 6 (6).

24: Khan, I.; Saeed, K.; Khan, I. Nanoparticles: Properties, Applications and Toxicities. Arabian Journal of Chemistry 2019, 12 (7), 908-931.

25: Lipton, S. A.; Choi, Y.-B.; Takahashi, H.; Zhang, D.; Li, W.; Godzik, A.; Bankston, L. A. Cysteine Regulation of Protein Function - as Exemplified by NMDA-Receptor Modulation. Trends in Neurosciences 2002, 25 (9), 474-480.

26: Kadokura, H.; Katzen, F.; Beckwith, J. Protein Disulfide Bond Formation in Prokaryotes. Annual Review of Biochemistry 2003, 72 (1), 111-135. 
27: Magnani, D.; Solioz, M. In Molecular Microbiology of Heavy Metals; Springer-Verlag: Heidelberg, 2007; pp 159-295.

28: Kirakosyan, G.; Trchounian, K.; Vardanyan, Z.; Trchounian, A. Copper (II) Ions Affect Escherichia Coli Membrane Vesicles' SH-Groups and a Disulfide-Dithiol Interchange Between Membrane Proteins. Cell Biochemistry and Biophysics 2008, 51 (1), 45-50.

29: Meireles, M.; Aimar, P.; Sanchez, V. Albumin Denaturation during Ultrafiltration: Effects of Operating Conditions and Consequences on Membrane Fouling. Biotechnology and Bioengineering 1991, 38 (5), 528-534.

30: Hussain, F.; Sedlak, E.; Wittung-Stafshede, P. Role of Copper in Folding and Stability of Cupredoxin-like Copper-Carrier Protein CopC. Archives of Biochemistry and Biophysics 2007, 467 (1), 58-66.

31: Dokken, K. M.; Parsons, J. G.; Mcclure, J.; Gardea-Torresdey, J. L. Synthesis and Structural Analysis of Copper(II) Cysteine Complexes. Inorganica Chimica Acta 2009, 362 (2), 395-401.

32: Hussain, F.; Wittung-Stafshede, P. Impact of Cofactor on Stability of Bacterial (CopZ) and Human
(Atox1) Copper Chaperones. Biochimica et Biophysica Acta (BBA) - Proteins and

Proteomics 2007, 1774 (10), 1316-1322.

33: Pecci, L.; Montefoschi, G.; Musci, G.; Cavallini, D. Novel Findings on the Copper Catalysed Oxidation of Cysteine. Amino Acids 1997, 13 (3-4), 355-367.

34: Harris, D. C. In Quantitative Chemical Analysis; W. H. Freeman and Company: New York, NY, 2007; pp AP20-AP27.

35: Victor Talrose, Alexander N. Yermakov, Alexy A. Usov, Antonina A. Goncharova, Axlexander N. Leskin, Natalia A. Messineva, Natalia V. Trusova, Margarita V. Efimkina, "UV/Visible Spectra" in NIST Chemistry WebBook, NIST Standard Reference Database Number 69, Eds. P.J. Linstrom and W.G. Mallard, National Institute of Standards and Technology, Gaithersburg MD, 20899, https://doi.org/10.18434/T4D303, (retrieved May 21, 2020).

36: Kruusma, J.; Benham, A. M.; Williams, J. A. G.; Kataky, R. An Introduction to Thiol Redox Proteins in the Endoplasmic Reticulum and a Review of Current Electrochemical Methods of Detection of Thiols. The Analyst 2006, 131 (4), 459. 


\section{APPENDIX A}

Antibacterial properties of copper nanowires and the role of copper
ion/cysteine interactions in bacterial membrane proteins
Morgan Stewart, Annie Jenike, Shankar B. Rananavare / Department of Chemistry, Portland State University, Portland, OR 97201.

\section{Abstract}

Antibacterial properties of copper nanostructures on Escherichia coli are presented. This study focuses on the effectiveness of antibacterial properties of copper nanoparticles or nanowires and explores cytotoxic mechanisms of copper ions. Previously observed E. Coli cell wall disruption can be understood in terms of membrane protein denaturation as seen through ultraviolet-visible spectroscopic studies of solutions of $\mathrm{Cu}(\mathrm{II}) / \mathrm{cysteine}$ complexes. The results of this study indicate that the $\mathrm{Cu}(\mathrm{I})$ ions were more effective than the $\mathrm{Cu}(\mathrm{II})$ ions and that there was a difference in the effectiveness of copper nanowires versus nanoparticles.$$
\begin{aligned}
& \text { Methods } \\
& \text { Copper nanowires were synthesized } \\
& \text { using a solution-based process. Data } \\
& \text { collection employed two disk diffusion } \\
& \text { assay procedures. The first method } \\
& \text { used five wells made in agar plates } \\
& \text { with } E \text {. coli, each with varying concen- } \\
& \text { trations of nanowires or nanoparticles } \\
& \text { followed by measuring the zone of } \\
& \text { inhibition. The second disc method } \\
& \text { consisted of distributing the desired } \\
& \text { concentration of nanowires and } \\
& \text { nanoparticles on to sterile disks of filter } \\
& \text { paper, which are placed into plated } E \text {. } \\
& \text { coli cultures followed by measuring the } \\
& \text { zone of inhibition. Cu(II) cysteine } \\
& \text { solutions are prepared in phosphate } \\
& \text { buffer solution at pH } 7 \text { and deaerated } \\
& \text { by nitrogen gas bubbling before } \\
& \text { Ultraviolet visible spectra were } \\
& \text { collected. }
\end{aligned}
$$

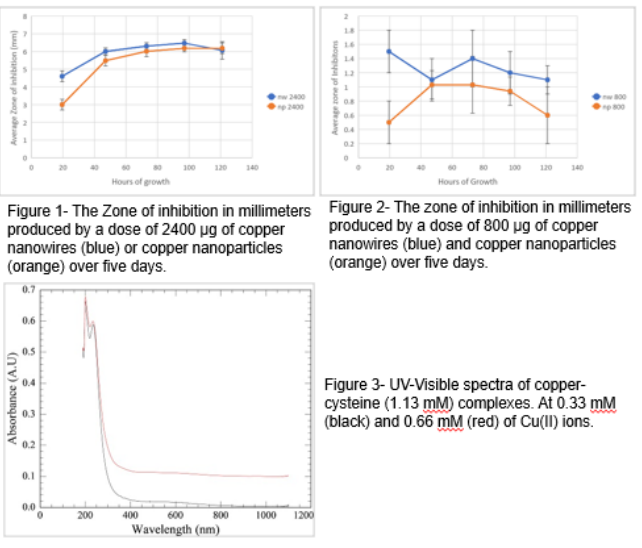

\section{Results}

The copper nanoparticles and nanowires were somewhat effective against $\mathrm{E}$. coli XL blue.

- The average zone of inhibition for copper nanoparticles at $800 \mu \mathrm{g}$ was less than $2 \mathrm{~mm}$ and at $2400 \mu \mathrm{g}$ it was $5.5 \mathrm{~mm}$ after 48 hours: the nanowires showed similar results with the $800 \mu \mathrm{g}$ showing an average zone of inhibition of $1 \mathrm{~mm}$ with the average zone for $2400 \mu \mathrm{g}$ being $6 \mathrm{~mm}$

e highest zone of inhibition shown at the $800 \mu \mathrm{g}$ dose of nanoparticles was in the first 24 hours.

- The largest zone of inhibition shown for 2400 dose was at 97 hours and was 6.5 and 6.2 for the nanowires and nanoparticles, respectively. - The average zone of inhibition for the ampicillin was $11 \mathrm{~mm}$ after 24 hours.

- The average zone of inhibition of $1200 \mu \mathrm{g}$ of copper nanoparticles at 24 hours was $2.4 \mathrm{~mm}$ and the zone of inhibition of copper nanowires at 24 hours was $3.3 \mathrm{~mm}$.

- The zone of inhibition of Cu(II) was $3.1 \mathrm{~mm}$ and the zone of inhibition of $\mathrm{Cu}(\mathrm{I})$ was $5.0 \mathrm{~mm}$.

Discussion
- Significant differences between the copper
nanoparticles and nanowires toxicity could be due
to the nature of their surface structures.
- The $\mathrm{Cu}(\mathrm{I})$ ions were more effective than the $\mathrm{Cu}(\mathrm{II})$
ions.

References 12igo, Adelio et al. "Interaction of copper with cysteine: stability of cuprous complexes and catalytic role of cupric ions in anaerobic thiol oxidation"
2Espirito Santo, Christophe et al. "Bacterial Killing by Dry Metallic Copper Surfaces" Applied and Environmental Microbiology 77.3 (2011): 794-802

$77^{\text {th }}$ Annual Meeting of the Oregon Academy of Science, McMinnville, Oregon. 23 ${ }^{\text {rd }}$ of February, 2019 
